\title{
Effectiveness of weed control in maize with two foliage treatments
}

\author{
Skuteczność zwalczania chwastów w kukurydzy \\ z użyciem dwóch zabiegów nalistnych
}

\author{
Roman Kierzek ${ }^{1}$, Adam Paradowski ${ }^{1}$, Joanna Pietryga ${ }^{2}$, Sylwia Kaczmarek ${ }^{1}$
}

\begin{abstract}
Summary
In the years 2011-2012, three field experiments were carried out in maize to evaluate effect of weed control with herbicides applied at reduced doses as two foliage treatments. Herbicides were applied in the following system: early foliage treatment at the 2-3 leaf stage of maize with Lumax 537,5 SE (s-metolachlor + terbuthylazine + mesotrione) at $1.5 \mathrm{l} / \mathrm{ha}$ and second treatment at the 5-7 leaf stage of maize with Hector 53,6 WG (nicosulfuron + rimsulfuron) at the $35 \mathrm{~g} / \mathrm{ha}$, Milagro $040 \mathrm{SC}$ (nicosulfuron) at $0.5 \mathrm{l} / \mathrm{ha}$, Titus 25 WG (rimsulfuron) at $30 \mathrm{~g} /$ ha or Maister 310 WG (foramsulfuron + iodosulfuron). Adjuvant Atpolan Bio $80 \mathrm{SL}$ at the dose of $1.0 \mathrm{l} / \mathrm{ha}$ was added to herbicides in the second foliage treatment. The conducted experiments showed the advantages of the application of two foliage treatments with the use of herbicides at reduced doses against Echinochloa crus-galli and broad-leaved weeds in maize. There were no symptoms of the phytotoxic effect of the applied herbicides found on maize plants in performed experiments. High effectiveness of weed control in maize with the use of different systems of herbicide application affected favorably maize yield and weight of 1000 grains. No effect on protein, oil and starch content was observed.
\end{abstract}

Key words: maize, weeds, herbicide, reduced doses, foliage treatment

\section{Streszczenie}

W latach 2011-2012 przeprowadzono trzy ścisłe doświadczenia ze stosowaniem herbicydów w dawkach obniżonych, w systemie dwóch zabiegów nalistnych w kukurydzy. Do pierwszego zabiegu w fazie 2-3 liści kukurydzy stosowano Lumax 537,5 SE (mezotrion + S-metolachlor + terbutyloazyna) w dawce 1,5 I/ha. Do następnych zabiegów w fazie 5-7 liści stosowano herbicydy: Hector 53,6 WG (nikosulfuron + rimsulfuron) w dawce $35 \mathrm{~g} /$ ha, Milagro $040 \mathrm{SC}$ (nikosulfuron) w dawce 0,5 I/ha, Titus 25 WG (rimsulfuron) w dawce $30 \mathrm{~g} /$ ha lub Maister 310 WG (foramsulfuron + jodosulfuron) w dawce $60 \mathrm{~g} / \mathrm{ha}$. Poszczególne dawki herbicydów były obniżone od podstawowych w granicach 40-50\%. W drugim zabiegu do wszystkich herbicydów dodano adiuwant Atpolan Bio 80 EC w dawce 1 l/ha. Zastosowane kombinacje wykazały bardzo dobry efekt w zwalczaniu chwastnicy jednostronnej oraz gatunków dwuliściennych. Nie wykazały fitotoksycznego działania w stosunku do kukurydzy. Stwierdzono istotny wpływ zastosowanego systemu odchwaszczania na przyrost plonu ziarna kukurydzy i wzrost masy 1000 ziaren. Nie stwierdzono wpływu zabiegów herbicydowych na procentową zawartość białka, tłuszczu i skrobi.

Słowa kluczowe: kukurydza, chwasty, herbicydy, dawki obniżone, zabieg nalistny

\footnotetext{
1 Instytut Ochrony Roślin - Państwowy Instytut Badawczy 


\section{Wstęp / Introduction}

Niekorzystny przebieg pogody w optymalnych okresach wykonywania zabiegów ochronnych jest przyczyną zmiennej efektywności chemicznych metod odchwaszczania kukurydzy. W takich warunkach szczególnie małą skutecznością działania odznaczają się herbicydy przedwschodowe (Dogan i wsp. 2004). Po okresie intensywnych opadów na wielu plantacjach obserwuje się masowe wschody nowych gatunków zwłaszcza chwastów ciepłolubnych. W takiej sytuacji może się okazać, że wcześniej wykonany zabieg doglebowy nie gwarantuje oczekiwanego poziomu ochrony plantacji przed zachwaszczeniem w krytycznym okresie wzrostu i rozwoju kukurydzy. Ciepły i wilgotny maj sprzyja szybkiemu rozwojowi chwastów (Gołębiowska 2006). W tym samym czasie występujące okresy niskiej temperatury i brak opadów obniżają skuteczność środków chwastobójczych w stosunku do chwastów pojawiających się później (Gołębiowska i Snopczyński 2008). Wykonanie dwóch zabiegów nalistnych w dawkach obniżonych, w sytuacji przeciagających się w czasie wschodów chwastów, wydaje się skutecznym działaniem, ograniczającym zachwaszczenie kukurydzy na początku oraz w późniejszym okresie wegetacji roślin. Ważny jest odpowiedni dobór mieszanin herbicydowych, ewentualnie herbicydów o szerokim spektrum działania, uwzględniających specyfikę zbiorowiska chwastów na polu.

Celem pracy była analiza efektywności ochrony kukurydzy przed zachwaszczeniem z użyciem dwóch zabiegów wykonanych w początkowej fazie wzrostu kukurydzy (2-3 liście) oraz w fazie 5-6 liści, w warunkach zróżnicowanych w czasie wschodów chwastów. Dawki herbicydów w poszczególnych zabiegach ograniczono do 40-50\% dawki zalecanej.

\section{Materiały i metody / Materials and methods}

W latach 2011 i 2012 na terenie gospodarstwa indywidualnego położonego w Gołuchowie koło Poznania założono dwa ścisłe doświadczenia polowe (A i B) w uprawie kukurydzy, w trzech powtórzeniach na poletkach o powierzchni 12,0 lub $12,5 \mathrm{~m}^{2}$. Według identycznego schematu w 2012 roku, w Nieborowicach (województwo śląskie) założono ścisłe doświadczenie polowe (C), w czterech powtórzeniach, na poletkach o powierzchni $20 \mathrm{~m}^{2}$. Przedplonem na wszystkich stanowiskach była kukurydza. Doświadczenia założono na glebie płowej wytworzonej z piasków gliniastych średnich o klasie bonitacyjnej od IIIa do IVa.

Podstawowym obiektem badawczym był herbicyd Lumax 537,5 SE stanowiący mieszaninę trzech substancji czynnych: mezotrionu $(37,7 \mathrm{~g} / \mathrm{l})$, S-metolachloru $(312,5 \mathrm{~g} / \mathrm{l})$ i terbutyloazyny $(187,5 \mathrm{~g} / \mathrm{l})$, stosowany w fazie 2-3 liści kukurydzy w obniżonej dawce, tj. 1,5 1/ha. W momencie osiągnięcia przez kukurydzę fazy 5-7 liści wykonywano drugi zabieg, jednym $\mathrm{z}$ następujących preparatów: Hector 53,6 WG (nikosulfuron 42,9\% + rimsulfuron $10,7 \%$ ) w dawce $35 \mathrm{~g} / \mathrm{ha}$, Milagro $040 \mathrm{SC}$ (nikosulfuron $40 \mathrm{~g} / \mathrm{l}$ ) $\mathrm{w}$ dawce $0,5 \mathrm{l} / \mathrm{ha}$, Titus $25 \mathrm{WG}$ (rimsulfuron 25\%) w dawce $30 \mathrm{~g} /$ ha oraz Maister $310 \mathrm{WG}$ (foramsulfuron $300 \mathrm{~g} / \mathrm{kg}+$ jodosulfuron metylosodowy $10 \mathrm{~g} / \mathrm{kg}$ ) W dawce $60 \mathrm{~g} / \mathrm{ha}$. W drugim zabiegu do wszystkich herbicydów dodano adiuwant Atpolan Bio $80 \mathrm{EC} \mathrm{w}$ dawce 1,01/ha.

Ocenę zachwaszczenia oraz fitotoksyczności wykonano metodą wizualną 3-4 oraz 8-11 tygodni po zabiegu. Plon określono i przeliczono na 1 hektar, po ręcznym zbiorze kolb z 2 rzędów środkowych. Określono masę 1000 ziaren oraz procentową zawartość białka, oleju i skrobi za pomocą analizatora jakości ziarna Infratec 1241. Plon i parametry jakościowe ziarna kukurydzy poddano ocenie statystycznej, wykorzystując analizę wariancji i test t-Studenta. Istotność zróżnicowania wyników oceniono przy poziomie ufności $\mathrm{p}=0,05$.

\section{Wyniki i dyskusja / Results and discussion}

\section{Ocena efektu chwastobójczego}

$\mathrm{Na}$ obiektach doświadczalnych licznie występowało 9 gatunków chwastów. Wśród chwastów jednoliściennych dominowała chwastnica jednostronna (Echinochloa crusgalli L.), średnio 26 szt. $/ \mathrm{m}^{2}$. Chwasty dwuliścienne były najliczniej reprezentowane przez psiankę czarną (Solanum nigrum L.) $23 \mathrm{szt} . / \mathrm{m}^{2}$, fiołka polnego (Viola arvensis Murr.) 22 szt. $/ \mathrm{m}^{2}$, komosą białą (Chenopodium album L.) 14 szt. $/ \mathrm{m}^{2}$, szarłat szorstki (Amarantus retroflexus L.) i tasznik pospolity [Capsella bursa-pastoris (L) Medik.] po 10 szt. $/ \mathrm{m}^{2}$. Rdest plamisty (Polygonum persicaria L.) i ptasi (Polygonum aviculare L.) oraz rdestówka powojowata (Fallopia convolvulus L.) występowały w granicach 7-8 szt. $/ \mathrm{m}^{2}$. Ponadto $\mathrm{w}$ mniejszym nasileniu stwierdzono Lamium purpureum L., Matricaria maritima L. subsp. indora (L.), Veronica persica Poir. Stanowiska należy zaliczyć do charakterystycznych, na których występują podstawowe uciążliwe gatunki dla kukurydzy (Gołębiowska i Kaus 2009).

Najsłabszy efekt chwastobójczy uzyskano w stosunku do E. crus-galli. Po pierwszej obserwacji skuteczność zniszczenia tego gatunku na obiekcie traktowanym niskimi dawkami herbicydów Lumax 537,5 SE, a następnie Hector 53,6 WG wynosiła zaledwie 83\% (tab. 1) i ostatecznie ukształtowała się na poziomie $88 \%$ (tab. 2). Na pozostałych kombinacjach $\mathrm{z}$ udziałem dwóch zabiegów nalistnych skuteczność zwalczania tego gatunku była wysoka i wahała się w granicach 96-98\%. W drugiej ocenie stwierdzono niewielki wzrost efektywności chwastobójczej do poziomu $98-99 \%$, potwierdzając tym samym korzystny efekt dwóch zabiegów w stosunku do tego gatunku. Sam Lumax 537,5 SC w pierwszej ocenie ograniczył występowanie E. crus-galli w 98\%. Wskutek nowych wschodów na przełomie maja i czerwca, efekt chwastobójczy obniżył się do $90 \%$, ale ze względu na szybki wzrost kukurydzy konkurencyjne oddziaływanie tego chwastu było niewielkie. W innych doświadczeniach Głowacki i wsp. (2007) po zastosowaniu w tym terminie takiej samej dawki uzyskali efekt zwalczania na poziomie $96 \%$.

Chwasty dwuliścienne (oprócz rodzaju Polygonum) zostały w końcowym efekcie zwalczone w 100\% na obiektach z użyciem dwóch zabiegów nalistnych. 
Tabela 1. Wpływ systemu zwalczania chwastów na efektywność chwastobójczą w uprawie kukurydzy - wczesna analiza zachwaszczenia (3-4* WAT) - średnie z 3 doświadczeń

Table 1. Effect of herbicide treatments on efficacy of weed control in maize - early estimation (3-4 WAT*) - average of three experiments

\begin{tabular}{|c|c|c|c|c|c|c|c|c|c|c|c|}
\hline \multirow[b]{2}{*}{$\begin{array}{c}\text { Obiekt doświadczalny } \\
\text { Treatment }\end{array}$} & \multirow{2}{*}{$\begin{array}{c}\text { Dawka na ha } \\
\text { Dose per ha } \\
{[1]}\end{array}$} & \multirow{2}{*}{$\begin{array}{l}\text { Termin } \\
\text { zabiegu } \\
\text { Time of } \\
\text { application }\end{array}$} & \multicolumn{9}{|c|}{ Zniszczenie chwastów - Weed control [\%] } \\
\hline & & & ECHCG & SOLNI & VIOAR & CHEAL & AMARE & FALCO & POLPE & CAPBP & POLAV \\
\hline $\begin{array}{l}\text { Kontrola }\left[\mathrm{szt} . / \mathrm{m}^{2}\right] \\
\left.\text { Untreated [pcs plants } / \mathrm{m}^{2}\right]\end{array}$ & - & - & 18 & 22 & 15 & 11 & 10 & 8 & 7 & 7 & 4 \\
\hline $\begin{array}{l}\text { Lumax 537,5 SE/Hector } \\
53,6 \mathrm{WG}+\text { Atpolan Bio } \\
80 \mathrm{SL}\end{array}$ & $\begin{array}{c}1,5 / 35 \mathrm{~g}+ \\
1,0\end{array}$ & $\mathrm{~T} 1 / \mathrm{T} 2$ & 83 & 99 & 100 & 100 & 100 & 99 & 100 & 100 & 91 \\
\hline $\begin{array}{l}\text { Lumax 537,5 SE/Milagro } \\
40 \mathrm{SC}+\text { Atpolan } 80 \mathrm{SL}\end{array}$ & $1,5 / 0,5+1,0$ & $\mathrm{~T} 1 / \mathrm{T} 2$ & 98 & 100 & 100 & 100 & 100 & 100 & 100 & 100 & 93 \\
\hline $\begin{array}{l}\text { Lumax 537,5 SE/Titus } \\
25 \mathrm{WG}+\text { Atpolan } 80 \mathrm{SL}\end{array}$ & $\begin{array}{c}1,530 \mathrm{~g}+ \\
1,0\end{array}$ & $\mathrm{~T} 1 / \mathrm{T} 2$ & 96 & 100 & 100 & 100 & 100 & 99 & 100 & 100 & 93 \\
\hline $\begin{array}{l}\text { Lumax 537,5 SE/Maister } \\
310 \mathrm{WG}+\text { Atpolan } 80 \mathrm{SL}\end{array}$ & $\begin{array}{c}1,5 / 60 \mathrm{~g}+ \\
1,0\end{array}$ & $\mathrm{~T} 1 / \mathrm{T} 2$ & 97 & 100 & 100 & 100 & 100 & 100 & 99 & 100 & 96 \\
\hline Lumax 537,5 SE & 3,5 & $\mathrm{~T} 1$ & 98 & 100 & 100 & 99 & 99 & 100 & 99 & 100 & 96 \\
\hline
\end{tabular}

T1 - kukurydza w fazie 2-3 liści - at the 2-3 leaf stage of maize, T2 - kukurydza w fazie 5-7 liści - at the 5-7 leaf stage of maize

ECHCG - Echinochloa crus-galli, SOLNI - Solanum nigrum, VIOAR - Viola arvensis, CHEAL - Chenopodium album, AMARE - Amaranthus retroflexus, FALCO - Fallopia convolvulus, POLPE - Polygonum persicaria, CAPBP - Capsella bursa-pastoris, POLAV - Polygonum aviculare

*WAT - tygodnie po zabiegu - weeks after treatment

Tabela 2. Wpływ systemu zwalczania chwastów na efektywność chwastobójczą w uprawie kukurydzy - późna analiza zachwaszczenia (8-11 WAT*) - średnie z 3 doświadczeń

Table 2. Effect of herbicide treatments on efficacy of weed control in maize - second late estimation (8-11 WAT*) - average of three experiments

\begin{tabular}{|c|c|c|c|c|c|c|c|c|c|c|c|}
\hline \multirow{2}{*}{$\begin{array}{l}\text { Obiekt doświadczalny } \\
\text { Treatment }\end{array}$} & \multirow{2}{*}{$\begin{array}{c}\text { Dawka } \\
\text { na ha } \\
\text { Dose per ha } \\
{[1]}\end{array}$} & \multirow{2}{*}{$\begin{array}{c}\text { Termin } \\
\text { zabiegu } \\
\text { Time of } \\
\text { application }\end{array}$} & \multicolumn{9}{|c|}{$\begin{array}{c}\text { Zniszczenie chwastów - Weed control } \\
{[\%]}\end{array}$} \\
\hline & & & ECHCG & SOLNI & VIOAR & CHEAL & AMARE & FALCO & POLPE & CAPBP & POLAV \\
\hline $\begin{array}{l}\text { Kontrola }\left[\mathrm{szt} . / \mathrm{m}^{2}\right] \\
\text { Untreated }\left[\mathrm{pcs} \text { plants } / \mathrm{m}^{2}\right]\end{array}$ & - & - & 26 & 23 & 22 & 14 & 10 & 8 & 7 & 10 & 7 \\
\hline $\begin{array}{l}\text { Lumax 537,5 SE/Hector 53,6 WG } \\
+ \text { Atpolan Bio } 80 \mathrm{SL}\end{array}$ & $\begin{array}{l}1,5 / 35 \mathrm{~g} \\
+1,0\end{array}$ & $\mathrm{~T} 1 / \mathrm{T} 2$ & 88 & 100 & 100 & 97 & 100 & 99 & 100 & 100 & 97 \\
\hline $\begin{array}{l}\text { Lumax 537,5 SE/Milagro } 40 \mathrm{SC} \\
+ \text { Atpolan } 80 \mathrm{SL} \\
\end{array}$ & $\begin{array}{c}1,5 / 0,5 \\
+1,0\end{array}$ & $\mathrm{~T} 1 / \mathrm{T} 2$ & 98 & 100 & 100 & 100 & 100 & 100 & 100 & 100 & 98 \\
\hline $\begin{array}{l}\text { Lumax } 537,5 \mathrm{SE} / \text { Titus } 25 \mathrm{WG} \\
+ \text { Atpolan } 80 \mathrm{SL}\end{array}$ & $\begin{array}{l}1,5 / 30 \mathrm{~g} \\
+1,0\end{array}$ & $\mathrm{~T} 1 / \mathrm{T} 2$ & 99 & 100 & 100 & 100 & 100 & 99 & 100 & 100 & 97 \\
\hline $\begin{array}{l}\text { Lumax 537,5 SE/Maister } 310 \mathrm{WG} \\
+ \text { Atpolan } 80 \mathrm{SL} \\
\end{array}$ & $\begin{array}{l}1,5 / 60 \mathrm{~g} \\
+1,0 \\
\end{array}$ & $\mathrm{~T} 1 / \mathrm{T} 2$ & 98 & 100 & 100 & 100 & 100 & 100 & 100 & 100 & 98 \\
\hline Lumax 537,5 SE & 3,5 & $\mathrm{~T} 1$ & 90 & 100 & 100 & 100 & 100 & 100 & 100 & 100 & 99 \\
\hline
\end{tabular}

T1 - kukurydza w fazie 2-3 liści - at the 2-3 leaf stage of maize, T2 - kukurydza w fazie 5-7 liści - at the 5-7 leaf stage of maize

ECHCG - Echinochloa crus-galli, SOLNI - Solanum nigrum, VIOAR - Viola arvensis, CHEAL - Chenopodium album, AMARE - Amaranthus retroflexus, FALCO - Fallopia convolvulus, POLPE - Polygonum persicaria, CAPBP - Capsella bursa-pastoris, POLAV - Polygonum aviculare

*WAT - tygodnie po zabiegu - weeks after treatment

W pierwszej ocenie $P$. persicaria i $F$. convolvulus zostały zniszczone w granicach $99-100 \%$, a $P$. aviculare $\mathrm{w}$ granicach $91-96 \%$ (tab. 1). Druga analiza wykazała niemal całkowite zniszczenie $P$. persicaria i $F$. convolvulus oraz wzrost skuteczności zwalczania $P$. aviculare do $97-98 \%$ (tab. 2). Sam Lumax 537,5 SE zwalczał $P$. aviculare w 96\%. Głowacki i wsp. (2007) oceniając wpływ preparatu Lumax 537,5 SE na ponad 20 jednorocznych gatunków dwuliściennych najsłabszy efekt uzyskali w zwalczaniu $P$. aviculare i $F$. convolvulus.

Uzyskany wysoki efekt chwastobójczy względem ocenianych gatunków chwastów był związany z łącznym stosowaniem do drugiego zabiegu adiuwanta Atpolan Bio 80 EC. Metoda wykorzystania dodatku różnych adiuwantów jest coraz bardziej popularna i opisana w wielu publikacjach naukowych (Skrzypczak i wsp. 1998; 
Tabela 3. Wpływ stosowanych zabiegów herbicydowych na plon oraz parametry ilościowo-jakościowe ziarna kukurydzy - średnia z trzech doświadczeń

Table 3. Effect of herbicide treatments on the yield and the quantitative and qualitative parameters of maize grains - average of three experiments

\begin{tabular}{|c|c|c|c|c|c|c|c|c|c|c|}
\hline \multirow{2}{*}{$\begin{array}{l}\text { Obiekt doświadczalny } \\
\text { Treatment }\end{array}$} & \multirow{2}{*}{$\begin{array}{c}\text { Dawka } \\
\text { na ha } \\
\text { Dose } \\
\text { per ha } \\
{[1]}\end{array}$} & \multirow{2}{*}{$\begin{array}{c}\text { Termin } \\
\text { zabiegu } \\
\text { Time of } \\
\text { application }\end{array}$} & \multicolumn{4}{|c|}{$\begin{array}{c}\text { Plon ziarna }- \text { Yield of grain } \\
{[\mathrm{t} / \mathrm{ha}]}\end{array}$} & \multirow{2}{*}{$\mid \begin{array}{c}\text { Srednia masa } \\
1000 \text { ziaren } \\
\text { Mean weight } \\
\text { of } 1000 \\
\text { grains }[\mathrm{g}]\end{array}$} & \multicolumn{3}{|c|}{$\begin{array}{c}\text { Średnia zawartość } \\
\text { Average content } \\
{[\%]}\end{array}$} \\
\hline & & & A & B & $\mathrm{C}$ & $\begin{array}{l}\text { średni } \\
\text { mean }\end{array}$ & & $\begin{array}{l}\text { olej } \\
\text { oil }\end{array}$ & $\begin{array}{l}\text { białko } \\
\text { protein }\end{array}$ & $\begin{array}{l}\text { skrobia } \\
\text { starch }\end{array}$ \\
\hline Kontrola - Untreated & - & - & $5,20 \mathrm{~b}$ & $8,35 \mathrm{~b}$ & $11,52 \mathrm{a}$ & $8,36 \mathrm{~b}$ & $333,9 \mathrm{~b}$ & $4,6 \mathrm{a}$ & $9,9 \mathrm{a}$ & $70,9 \mathrm{a}$ \\
\hline $\begin{array}{l}\text { Lumax 537,5 SE/Hector } \\
53,6 \mathrm{WG}+\text { Atpolan Bio } \\
80 \mathrm{SL}\end{array}$ & $\begin{array}{l}1,5 / 35 \mathrm{~g} \\
+1,0\end{array}$ & $\mathrm{~T} 1 / \mathrm{T} 2$ & 10,99 a & $11,80 \mathrm{ab}$ & $13,88 \mathrm{a}$ & $12,22 \mathrm{a}$ & $352,4 \mathrm{ab}$ & $4,7 \mathrm{a}$ & $10,3 \mathrm{a}$ & $70,5 \mathrm{a}$ \\
\hline $\begin{array}{l}\text { Lumax } 537,5 \mathrm{SE} / \text { Milagro } \\
40 \mathrm{SC}+\text { Atpolan } 80 \mathrm{SL}\end{array}$ & $\begin{array}{l}1,5 / 0,5 \\
+1,0\end{array}$ & $\mathrm{~T} 1 / \mathrm{T} 2$ & $10,20 \mathrm{a}$ & $11,88 \mathrm{ab}$ & $14,71 \mathrm{a}$ & $12,26 \mathrm{a}$ & $348,8 \mathrm{ab}$ & $4,7 \mathrm{a}$ & $10,3 \mathrm{a}$ & $70,7 \mathrm{a}$ \\
\hline $\begin{array}{l}\text { Lumax } 537,5 \mathrm{SE} / \text { Titus } \\
25 \mathrm{WG}+\text { Atpolan } 80 \mathrm{SL}\end{array}$ & $\begin{array}{l}1,5 / 30 \mathrm{~g} \\
+1,0\end{array}$ & $\mathrm{~T} 1 / \mathrm{T} 2$ & $10,02 \mathrm{a}$ & $13,02 \mathrm{a}$ & $14,70 \mathrm{a}$ & $12,58 \mathrm{a}$ & $343,9 \mathrm{ab}$ & $4,6 \mathrm{a}$ & $10,1 \mathrm{a}$ & $70,8 \mathrm{a}$ \\
\hline $\begin{array}{l}\text { Lumax 537,5 SE/Maister } \\
310 \mathrm{WG}+\text { Atpolan } 80 \mathrm{SL} \\
\end{array}$ & $\begin{array}{l}1,5 / 60 \mathrm{~g} \\
+1,0 \\
\end{array}$ & $\mathrm{~T} 1 / \mathrm{T} 2$ & $11,51 \mathrm{a}$ & $12,39 \mathrm{ab}$ & $14,30 \mathrm{a}$ & $12,73 \mathrm{a}$ & 364,7 a & $4,7 \mathrm{a}$ & $10,4 \mathrm{a}$ & $70,4 \mathrm{a}$ \\
\hline Lumax 537,5 SE & 3,5 & $\mathrm{~T} 1$ & $11,84 \mathrm{a}$ & $12,48 \mathrm{a}$ & $14,21 \mathrm{a}$ & $12,84 \mathrm{a}$ & $355,2 \mathrm{ab}$ & $4,7 \mathrm{a}$ & $10,5 \mathrm{a}$ & $70,4 \mathrm{a}$ \\
\hline
\end{tabular}

Średnie w kolumnach oznaczone tymi samymi literami nie różnią się istotnie przy $\alpha=0,05$ - Means in columns folllowed by the same letters do not differ singnificantly at $\alpha=0.05$

T1 - kukurydza w fazie 2-3 liści - at the 2-3 leaf stage of maize, T2 - kukurydza w fazie 5-7 liści - at the 5-7 leaf stage of maize

A - doświadczenie w 2011 roku (Głuchowo koło Poznania) - experience in 2011 (Głuchowo near Poznan)

B - doświadczenie w 2012 roku (Głuchowo koło Poznania) - experience in 2012 (Głuchowo near Poznan)

C - doświadczenie w 2012 roku (Nieborowice - województwo śląskie) - experience in 2012 (Nieborowice - province Silesian)

Woźnica i Skrzypczak 1998; Zabkiewicz 2000; Kierzek i Miklaszewska 2009; Drzewiecki i Pietryga 2011).

W obydwóch latach badań (2011 i 2012), w pierwszych tygodniach wegetacji kukurydzy panowały korzystne warunki wilgotnościowe, stąd też skuteczność działania środka Lumax 537,5 SE (wykazuje bardzo dobre działanie doglebowe, jak i nalistne) aplikowanego w pełnej dawce w fazie 2-3 liści kukurydzy była wysoka zarówno w stosunku do rozciągniętych w czasie wschodów E. crus-galli, jak i chwastów dwuliściennych. Skutkowało to bardzo dobrym zabezpieczeniem plantacji kukurydzy przed zachwaszczeniem w długim okresie czasu, a efekty były porównywalne ze skutecznością działania dwóch zabiegów nalistnych z użyciem różnych herbicydów w obniżonych dawkach.

Skutkiem niewłaściwego doboru herbicydów i stąd niskiej skuteczności chwastobójczej jest pojawianie się w drugiej połowie wegetacji zachwaszczenia wtórnego, co z kolei wiąże się ze spadkiem plonowania i zanieczyszczeniem ziarna (Gołębiowska i Snopczyński 2008; Gołębiowska i Kaus 2009; Kierzek i wsp. 2012). Stąd też bardzo ważny jest dobór mieszanin herbicydowych, ewentualnie herbicydów o szerokim spektrum działania (np. zawierających kilka substancji czynnych), jednocześnie uwzględniających specyfikę zbiorowiska chwastów na polu (Skrzypczak i wsp. 2007). W przypadku wystąpienia nierównomiernych wschodów chwastów i korzystnych warunków pogodowych zalecić można stosowanie dwóch zabiegów z użyciem herbicydów w systemie dawek dzielonych lub obniżonych. Celowość takich działań udowodniono w niniejszej pracy i innych publikacjach (Skrzypczak i wsp. 2007; Kierzek i Adam- czewski 2008; Kierzek i Miklaszewska 2009; Kierzek i wsp. 2011).

Testowany system aplikacji herbicydów w dwóch zabiegach nalistnych dawkami obniżonymi odznaczał się szerokim zakresem ochrony w początkowym okresie wegetacji kukurydzy, zabezpieczając jednocześnie plantację przed zachwaszczeniem wtórnym. Tego typu systemy ochrony są bardziej bezpieczne dla środowiska i znacznie efektywniejsze w przypadku nierównomiernych i przeciągających się w czasie wschodów chwastów, szczególnie gatunków ciepłolubnych. Przyczyniają się także do uzyskania zadawalającego efektu ekonomicznego, gdyż sumaryczne dawki dwóch herbicydów są z reguły mniejsze od pełnej dawki herbicydu stosowanego jednorazowo (Paradowski i Kierzek 2009). W przypadku występowania na początku wegetacji kukurydzy małego zachwaszczenia lub gatunków tylko dwuliściennych dobrym rozwiązaniem jest stosowanie do pierwszego zabiegu tańszych herbicydów w znacznie obniżonych dawkach.

\section{Wpływ stosowanej ochrony na rozwój roślin kukurydzy}

Wysoka skuteczność zwalczania chwastów umożliwiła prawidłowy rozwój kukurydzy, co skutkowało uzyskaniem wysokich i jakościowo dobrych plonów ziarna kukurydzy. Plon ziarna $\mathrm{z}$ obiektu kontrolnego wyniósł średnio dla trzech doświadczeń 8,36 t/ha i był niższy niż na obiektach traktowanych herbicydami nawet o ponad 3,5 t/ha. Wysokie plony stwierdzono w kombinacjach, na których stosowano system dwóch zabiegów z użyciem herbicydów w dawkach obniżonych $(12,22-12,73 \mathrm{t} / \mathrm{ha})$. Plony te były 
istotnie wyższe od plonu ziarna zebranego $\mathrm{z}$ nietraktowanej herbicydami kontroli, powodując przyrost masy ziarna kukurydzy w granicach 46 do $52 \%$ (tab. 3). Jest to potwierdzeniem dobrej skuteczności badanych systemów odchwaszczania. Również Knezević i wsp. (2003) stosując dawki dzielone oraz obniżone wykazali istotny przyrost plonów. Podobne wyniki uzyskali Gołębiowska i Snopczyński (2008) oraz Kierzek i wsp. (2012) w badaniach nad zagrożeniem kukurydzy zachwaszczeniem wtórnym na tle zróżnicowanego przebiegu pogody oraz Drzewiecki i Pietryga (2011) podczas analizy plonu ziarna kukurydzy po aplikacji mieszanin herbicydów metodą dawek dzielonych łącznie $\mathrm{z}$ adiuwantem Atpolan Bio 80 EC.

Wizualna analiza zastosowanych herbicydów w różnych kombinacjach doświadczalnych nie wykazała fitotoksycznych objawów działania na rośliny kukurydzy. Bazowy herbicyd Lumax 537,5 SE testowany także w badaniach Głowackiego i wsp. (2007) w dawce nawet dwukrotnie wyższej od zalecanej $(8,0$ l/ha) odznaczał się niecałkowitą selektywnością dla kukurydzy.

Najniższa masa 1000 ziaren kukurydzy była zebrana z kolb na obiekcie kontrolnym $(333,9$ g). Na obiektach doświadczalnych stwierdzono zwiększoną od 10,0 do 30,8 g masę 1000 ziarniaków. Analiza na zawartość oleju, białka i skrobi była bardzo mało zróżnicowana. Zawartość oleju w ziarnie z kontroli wynosiła 4,6\%, na kombinacjach testowanych $\mathrm{z}$ użyciem dwóch zabiegów i porównawczej była podobna. Zawartość białka w ziarnie $\mathrm{z}$ obiektu kontrolnego wyniosła $9,9 \%$, a na pozostałych obiektach była nieco wyższa o $0,2-0,6 \%$. Zawartość skrobi w ziarnie we wszystkich testowanych obiektach doświadczalnych i kontroli była na zbliżonym poziomie.

\section{Wnioski / Conclusions}

1. W warunkach nierównomiernych i przedłużających się wschodów chwastów system ochrony kukurydzy oparty o dwa zabiegi nalistne z użyciem herbicydów w dawkach obniżonych umożliwia lepszy wybór środków do aktualnego stanu zachwaszczenia, jednocześnie skuteczniej i dłużej zabezpiecza plantację przed chwastami.

2. Bardzo dobre efekty zwalczania zarówno E. crus-galli, jak i gatunków dwuliściennych stwierdzono w układzie dwóch zabiegów, w których do pierwszego bazowego zabiegu nalistnego w fazie 2-3 liści kukurydzy użyto herbicyd Lumax 537,5 SE w ponad dwukrotnie niższej dawce od zalecanej, a następnie w fazie 5-7 liści kukurydzy herbicydy Hector 53,6 WG, Milagro 040 SC, Titus 25 WG lub Maister 310 WG w dawkach obniżonych i z dodatkiem adiuwanta Atpolan Bio 80 EC.

3. $\mathrm{Na}$ poletkach efektywnie chronionych za pomoca dwóch nalistnych zabiegów chwastobójczych, uzyskano wysoki plon ziarna kukurydzy, który był istotnie wyższy od niechronionej kombinacji kontrolnej w granicach $46-52 \%$.

4. Analiza zawartości oleju, białka i skrobi wykazała brak wpływu zastosowanych herbicydów na oznaczane parametry jakościowe ziarna kukurydzy.

5. System dwóch zabiegów skutecznie eliminując konkurencyjne oddziaływanie chwastów, nie powodował ujemnego wpływu na wzrost i rozwój roślin kukurydzy. Takie rozwiązanie jest bardziej bezpieczne dla środowiska i pozwala na uzyskanie zadawalającego efektu ekonomicznego dzięki stosowaniu sumarycznie mniejszych dawek substancji czynnych na hektar.

\section{Literatura / References}

Dogan M.N., Unay A., Boz O., Albay F. 2004. Determination of optimum weed control timing in maize (Zea mays L.). Turk. J. Agric. For. 28: 349-354.

Drzewiecki S., Pietryga J. 2011. Wpływ adiuwantów oraz metody dawek dzielonych herbicydów na ich skuteczność w uprawie kukurydzy. [The effect of adjuvants and split dose of herbicide application on their effectiveness in maize]. Prog. Plant Prot./Post. Ochr. Roślin 51 (3): 1349-1354.

Głowacki G., Stachecki S., Urban M., Górniak J. 2007. Skuteczność działania herbicydu Lumax 537,5 SE w zwalczaniu chwastów jedno- i dwuliściennych w uprawie kukurydzy. [Estimation of Lumax 537,5 SE effectiveness in mono and dicotylenous weed control in maize]. Prog. Plant Prot./Post. Ochr. Roślin 47 (3): 86-89.

Gołębiowska H. 2006. Wpływ sposobu aplikacji herbicydów na poziom zachwaszczenia wtórnego w kukurydzy. [Influence of methods of herbicide application on the secondary weed infestation in maize]. Prog. Plant Prot./Post. Ochr. Roślin 46 (2): $265-268$.

Gołębiowska H., Snopczyński T. 2008. Wzrost zagrożenia zachwaszczeniem wtórnym na plantacji kukurydzy na tle zróżnicowanego przebiegu pogody. [The increase od secondary weed infestation threat on maize crop field in relations to changing weather conditions]. Prog. Plant Prot./Post. Ochr. Roślin 48 (2): 602-611.

Gołębiowska H., Kaus A. 2009. Wpływ zróżnicowanych systemów uprawy na stan zachwaszczenia kukurydzy. [Influence of diversified tillage systems on weed infestation in crop maize]. Prog. Plant Prot./Post. Ochr. Roślin 49 (2): 792-796.

Kierzek R., Adamczewski K. 2008. Możliwości łącznego stosowania mieszanin herbicydów w kukurydzy. [Activity of selected herbicide mixtures in maize]. Prog. Plant Prot./Post. Ochr. Roślin 48 (3): 1146-1149.

Kierzek R., Miklaszewska K. 2009. Redukcja zachwaszczenia kukurydzy poprzez stosowanie herbicydów z adiuwantami oraz różnymi technologiami uprawy. [Weed control in maize by using herbicides with adjuvants and different technologies od weeding]. Prog. Plant Prot./Post. Ochr. Roślin 49 (2): 811-818.

Kierzek R., Paradowski A., Krawczyk R. 2011. Effectiveness of weed control in maize (Zea mays L.) depending on the date and method of herbicide application. Acta Sci. Pol., Agricultura 10 (2): 57-73. 
Kierzek R., Paradowski A., Kaczmarek S. 2012. Chemical methods of weed control in maize (Zea mays L.) in variable weather conditions. Acta Sci. Pol., Agricultura 11 (4): 35-52.

Knezevic M., Durkic M., Knezevic I., Loncaric Z. 2003. Effects of pre- and post-emergence weed control on weed population and maize yield in different tillage systems. Plant Soil Environ. 49 (5): 223-229.

Paradowski A., Kierzek R., 2009. Ekonomiczne aspekty chemicznego odchwaszczania kukurydzy po wycofaniu atrazyny. [Economic aspects of weed control in maize after atrazine with drawal]. Prog. Plant Prot./Post. Ochr. Roślin 49 (4): 1630-1636.

Skrzypczak G., Pudełko J., Blecharczyk A., 1998. Ocena działania herbicydów i adiuwantów w uprawie kukurydzy. [Effectiveness of herbicides and adjuvants in maize]. Prog. Plant Prot./Post. Ochr. Roślin 38 (2): 698-700.

Skrzypczak G., Pudełko J., Waniorek W. 2007. Assessment of the tank mixture of mesotrione and penhoxamid plus terbuthylazine efficacy for weed control in maize (Zea mays L.). J. Plant Prot. Res. 47 (4): 375-381.

Woźnica Z., Skrzypczak G. 1998. Adjuvants for foliar applied herbicides. Ann. Warsaw Agric. University, Agriculture 32: 33-42.

Zabkiewicz J.A. 2000. Adjuvants and herbicidal efficacy - present status and future prospects. Weed Res. 40: 139-149. 